\title{
The Assessment of Food Habits in Children and the Risk of Premature Tooth Extraction
}

\author{
Radosveta Stojanova Andreeva \\ Department of Pediatric Dentistry, Medical University of Varna
}

\begin{abstract}
The improper food habits are one of the most important risk factors for caries development and premature tooth extraction. The aim of this study is to assess the food habits of children with prematurely tooth loss compared to the healthy children. Methods and materials: The study covers 140 children between 6 and 9 years old. The control group consists of 50 children and the clinical group consists of 90 children with prematurely extracted teeth. The patients from the clinical group were divided into three groups of 30 patients. The control group consists of 50 children with intact denture. A special questionnaire was filled from the parents of the examined children about frequency of carbohydrate intake of their children. Results: Only a few percentage of children from the first and control group have a proper food habits and take carbohydrates rarely as a dessert-7, 1\% and 14, 3\% respectively. Most of the children eat simple sugar between mealscontrol group 55, 1\%; group 1-57, 1\%; group 2-70\%; group 3-50\%. Half of the children from the third group take carbohydrates often, anytime. Conclusions: The both groups of children (with and without prematurely extracted teeth) have unbalanced nutrition, connected with an increased take of simple sugar. The frequent intake of low-molecular carbohydrates, increase for a long period the acidic proliferation of tooth plaque microorganisms, being one of the underlying etiological factors of caries development and premature tooth loss.
\end{abstract}

Keywords: caries; sugars; eating habits

\section{Introduction}

Proper nutrition is necessary for the growth and development of children. The excessive in take of low-molecular carbohydrates is a serious heal this sue, which renders, unfavorable impact on the dental health $[1,2,3]$.The premature tooth loss is mainly due to the caries lesions and its complications[4]. The presence of fermentable carbohydrates changes the oral environment. Three main factors play a role in the dental caries process $[5,6,7,8]$ : the cariogenic potential of fermentable carbohydrates, the physical traits of fermentable carbohydrates, and the frequency of intake of, and exposure to, fermentable carbohydrates. When the organic acids a reproduced by the bacteria in dental plaque on the tooth surface they readilydiffuse in all directions and of course diffuse through the pores of enamelordentine and into the underlying tissue. As the acid diffuses in to the tooth it finds acid soluble mineral and begins to dissolve it $[9,10$, 11]. If this process progresses long enough, the end result is a cavity. This process in the mouth usually takes many months or years to progress to cavitation, the end-point of the disease process known as dental caries. If adequate measures are not taken caries is complicated in the pulpitis and periodontitis and sometimesitleads to premature tooth extraction[12, 13, 14, 15].

The aim of this study is to assess the food habits of children with prematurely tooth loss compared to the healthy children.

\section{Methods and Materials}

The study covers 140 children between 6 and 9 years old. The control group consists of 50 children and the clinical group consists of 90 children with prematurely extracted teeth. The patients from the clinical group were divided into three groups of 30 patients.
- Patients that have lost one or more tooth extracted in the dental clinic, of that come to the clinic during the first 2 month after the extraction and have no orthodontic problems.

- Patients with premature temporary teeth extraction 6 or more month before they come to the dental office without severe orthodontic problems.

- Patients with premature temporary tooth extraction and have severe orthodontic problems (II and III class Angle).

The control group consists of 50 children with intact denture.

A special questionnaire was filled from the parents of the examined children about frequency of carbohydrate intake of their children

\section{Results}

The reported result reveal an increased intake of simple sugar in the third surveyed group compared to the control group. Only a few percentage of children from the first and control group have a proper food habits and take carbohydrates rarely as a dessert $-7,1 \%$ and $14,3 \%$ respectively. Most of the children eat simple sugar between meals-control group 55, 1\%; group1 - 57, 1\%; group2 $70 \%$; group $3-50 \%$. Half of the children from the third group take carbohydrates often, anytime. Although not reaching the required level of statistical significance $(\mathrm{P}=$ 0.06), the difference in the distribution of the groups on the answer to the question "How often child takes carbohydrate foods" tends to more frequent use of carbohydrate foods in the groups studied (Table 1). 


\section{International Journal of Science and Research (IJSR) \\ ISSN (Online): 2319-7064}

Index Copernicus Value (2013): 6.14 | Impact Factor (2015): 6.391

Table 1: Distribution of children surveyed groups depending on thefrequency of carbohydrate intake

\begin{tabular}{|c|c|c|c|c|c|c|c|c|}
\hline \multirow{3}{*}{ Group } & \multicolumn{6}{|c|}{ How often the child takes carbohydrate foods } & \multirow{2}{*}{\multicolumn{2}{|c|}{ Total }} \\
\hline & \multicolumn{2}{|c|}{ Rearly, as a dessert } & \multicolumn{2}{|c|}{ Rearly, between meals } & \multicolumn{2}{|c|}{ Often, anytime } & & \\
\hline & Number & $\%$ & Number & $\%$ & Number & $\%$ & Number & $\%$ \\
\hline Control group & 7 & 14.3 & 27 & 55.1 & 15 & 30.6 & 49 & 100 \\
\hline Group 1 & 2 & 7.1 & 16 & 57.1 & 10 & 35.7 & 28 & 100 \\
\hline Group 2 & 0 & 0.0 & 21 & 70.0 & 9 & 30.0 & 30 & 100 \\
\hline Group 3 & 0 & 0.0 & 15 & 50.0 & 15 & 50.0 & 30 & 100 \\
\hline \multicolumn{2}{|c|}{ Statistical significance } & \multicolumn{7}{|c|}{$\mathrm{x}^{2}=11.89, \mathrm{df}=6, \mathrm{P}=0.06$} \\
\hline
\end{tabular}

\section{Discussion}

These results indicate poor eating habits of most of the children surveyed groups (with premature extracted deciduous teeth). Similar results have been reported in some other studies $[5,6,8]$.On the other hand, the lack of statistical significance, and the equivalent percentage of children in the control and the second study group, who consume carbohydrate often, proves the impact of other factors on premature extraction of primary teeth.

\section{Conclusions}

The both groups of children (with and without prematurely extracted teeth) have unbalanced nutrition, connected with an increased take of simple sugar. The frequent intake of low-molecular carbohydrates, increase for a long period the acidic proliferation of tooth plaque microorganisms, being one of the underlying etiological factors of caries development and premature tooth loss.

\section{References}

[1] Feather stone JDB. The caries balance: the basis for caries management by risk assessment. Oral Health PrevDent. 2004;2(1):259-264.

[2] Gorton J, Featherstone JDB. Invivo inhibition of demineralization around orthodontic brackets. Am J Orthod DentofacOrthop. 2003;123:10-14.

[3] Kashket S, Zhang J, VanHoute J. Accumulation of ferment able sugars and metabolic acids in food particles that become entrapped on the dentition. J Dent Res. 1996;75(11):1885-1891.

[4] Vadiakas G. Casedefinition, aetiologyandriskassessment of earlychildhoodcaries (ECC): a revisitedreview. EurArchPaediatrDent. 2008;9(3):114-125.

[5] Konstantinova, D., M. Dimova: Multicausal functional changes in masticatory system in boys and girls in higher school age, Practical Pediatrics, 2015, 2, XVIII, 20-23

[6] Konstantinova, D., R. Pancheva, M. Dimova: Trendsinthedentalstatusingirlsandboys of higherschoolageinVarna, Practical Pediatrics, 2013, 7, 16-18

[7] Konstantinova, D., M. Dimova: A Comparative study on the advantages and disadvantages of using natural vs. artificial food samples, Knowledge, International journal, Scientific and Applicative Papers, 2015, 8/1, 28-32

[8] Konstantinova, D., M. Dimova, D. Naydenova: Impact of foodpreferencesonthedevelopment of changes in the masticatory apparatus in young patients, 26-th Annual Assembly IMAB, 1215.05.2016, Varna, Bulgaria, oral presentation

[9] Marsh PD, Martin M. OralMicrobiology. 5th ed. ChurchillLivingstoneElsevier, London, UK. 2009.

[10] Sissons CH, Wong L, Shu M. FactorsaffectingtherestingpH of invitro human micro cosmdental plaque and Streptococcusmutansbiofilms. ArchOralBiol. 1998;43(2):93-102.

[11] Stookey GK. Theeffect of salivaondentalcaries. J AmDentAssoc. 2008;139:11S-17S.

[12] Ahn SJ, Ahn SJ, Browngardt CM, Burne RA. Changesinbiochemicalandphenotypic properties of Streptococcusmutansduringgrowthwithaeration. ApplEnvironMicrobiol. 2009;75(8):2517-2527.

[13] Shu M, Morou-Bermudez E, Suárez-Pérez E, etal. The relationship between dental caries status and dental plaque urease activity. OralMicrobiolImmunol. 2007;22(1):61-66.

[14] Edgar WM, Dawes C andO'Mullane D. Saliva and Oral Health. 3rd ed.BDJ Books, London, UK. 2004.

[15] Featherstone JD. Dentalcaries: a dynamic disease process. AustDent J. 2008;53(3):286-291.

\section{Author Profile}

Radosveta Andreeva is Faculty of Dental Medicine, Medical University of Varna 55 Marin Drinov Str. 9002 Varna, Bulgaria 